International Journal of Current Advanced Research

ISSN: O: 2319-6475, ISSN: P: 2319 - 6505, Impact Factor: SJIF: 5.995

Available Online at www.journalijcar.org

Volume 6; Issue 3; March 2017; Page No. 2890-2893

DOI: http://dx.doi.org/10.24327/ijcar.2017.2893.0134

\title{
ESTIMATION OF INDIVIDUAL HEIGHT IN CORRELATION WITH FEMUR LENGTH
}

\author{
Dharahaas
}

Saveetha Dental College

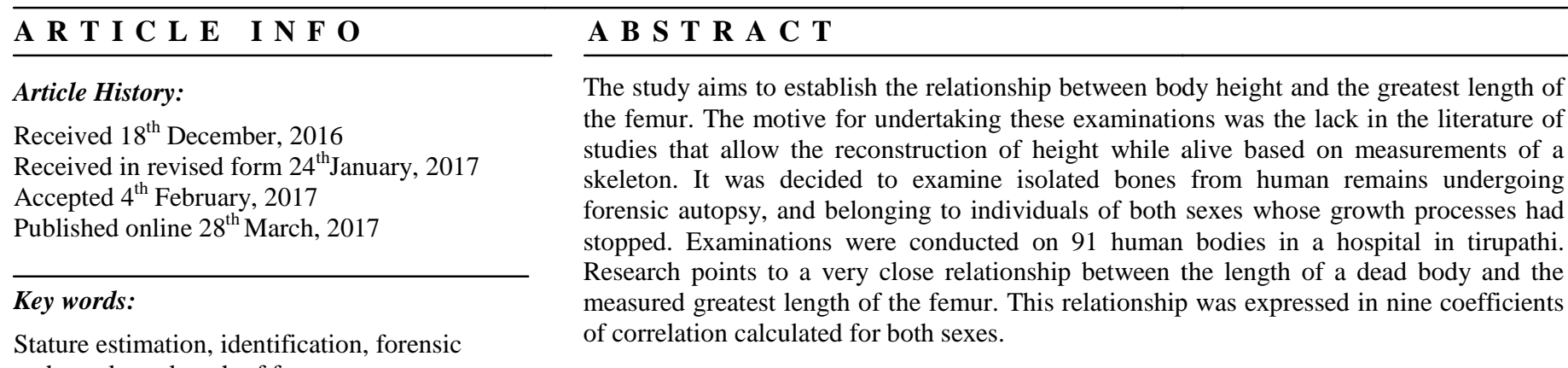

anthropology, length of femur.

Copyright $\bigcirc 2017$ Dharahaas. This is an open access article distributed under the Creative Commons Attribution License, which permits unrestricted use, distribution, and reproduction in any medium, provided the original work is properly cited.

\section{INTRODUCTION}

The length of the body while alive is one of the key parameters of identity established in the course of the identification of unknown remains. The reconstruction of body length has been a $\mathrm{z}$ subject of study since the beginning of the nineteenth century. The authors of the oldest methods, which are of purely historical importance, are: Orfilla [1], Langer [2], Toldt [3], Topinard [4] and Beddoe [5]. In 1888, Rollet-on the basis of the measurements of long bones taken from French remains-established the common factors by which their length is to be multiplied in order to work out the length of the remains [6]. He indicated that dry bones are shorter, relative to fresh bones, by approximately $2 \mathrm{~mm}$. Manouverier began more recent research into height reconstruction in 1893. He studied part of the bone material examined by Rollet [7]. In his calculations, he took into consideration the differences in the proportions of limbs and height depending on body length, and also the influence of involutionary processes on body length. He was the first to assert - contrary to opinion up to that time-that height is a function of the length of the long bones. Rollet's material was further evaluated by Pearson in 1899. In his study, Pearson employed statistical methods not used by his predecessors: the correlation of features and linear regression [8]. This allowed him to introduce new formulae that permitted the calculation of human height on the basis of bone measurements. He recognized, however, that as a result of the sharp differentiation of body length among people, these formulae

*Corresponding author: Dharahaas

Saveetha Dental College can only be used when they are applied to the population groups on the basis of whose data they were developed. Pearson further drew attention to the lengthening of the body that occurs after death: by $1.2 \mathrm{~cm}$ in the case of men, and by 2 $\mathrm{cm}$ in the case of women. In 1950, Telkkä-recognizing the necessity of applying differing formulae to different populations in order to reconstruct height, proposed new models for the population of Northern Europe and, concretely, for the Finns that had been the subject of his research [10]. He was the first researcher to introduce into his calculations corrections resulting from the differences he had observed between the length of bones on the right and left sides of the body. In 1951, Dupertuis and Hadden published their study, which also took into consideration black individuals [11]. These authors' method, however, turned out to be rather useless: its failing was that it took measurements of height from remains suspended by the external auditory meati; this meant that the body lengths established by this method were greater than height when alive. Some of the best studies of the reconstruction of body length while alive are those of Trotter and Gleser from 1952 to 1958 [[12], [13]]. In the first stage of their research (1952), these authors had at their disposal the remains of black and white American soldiers who had died during World War II [12]. Body length had been measured while the subjects were alive; bones taken from the remains were macerated. The authors of the study established that, beginning from his thirtieth year, the height of a human being lessens each year by $0.06 \mathrm{~cm}$, and they proved that after death body length increases by $2.5 \mathrm{~cm}$. Trotter and Gleser (1958) conducted similar research based on the quantitatively large amount of bone material from the dead of the Korean War, 
who belonged to varying ethnic groups: White, AfricanAmerican, Asian, Mexican and Puerto Rican [13]. The authors demonstrated significant differences in height-limb proportions between the materials from both studies, pointing to the necessity of periodic verification of the equations that serve to reconstruct height.

\section{MATERIALS AND METHODS}

Examinations were conducted on 91 human bodies from the current Indian population, in a hospital in tirupathi undergoing forensic examination. Bodies were chosen that were subject to rigor mortis, without obvious bodily deformation, and with clearly formed features of skeletal maturity. As a consequence of the possibility, in the case of women, of the easy visibility of the bodies' state after the removal of bones, the number of individuals of the female sex examined-out of consideration for the families of the deceased-had to be limited. The remains studied belonged to 71 men with body lengths from 157.5 to $192.7 \mathrm{~cm}$, between the ages of 19 and 87 , and also to 20 women with body length from 155.7 to $168 \mathrm{~cm}$, between the ages of 28 and 74 .

Device for measuring long bones-an osteometer specially devised, permitting measurements with a precision of $0.1 \mathrm{~mm}$ Two steel squares with 40 and $60 \mathrm{~cm}$ sides.

Steel measuring tape-3 $\mathrm{m}$ in length with $\mathrm{mm}$ divisions.

Polyethylene block-rectangular, dimensions $40 \mathrm{~cm} \times 40 \mathrm{~cm} \times$ $40 \mathrm{~cm}$.

The naked bodies were placed on their backs on the flat steel surface of the dissecting table. The lower limbs were straightened at the joints. The Achilles tendon was cut through on both sides. A block $3.5 \mathrm{~cm}$ in width was placed under the head in order to place the frankfurt plane perpendicular to the surface of the table.

One of the squares was placed so that the outer edge of its shorter side lay on the surface of the dissecting table; kthe inner edge of the longer side touched the vertex point at the top of the head. The square was stabilized. The surface of the feet was placed on one of the surfaces of the polyethylene block lying on the table. The block was stabilized. The second square was placed on the table in a similar way to the first; in this case, the inner edge of its longer side ran along the surface of the block touching the feet. The square was stabilized. By means of the measuring tape, with the participation of two people, the distance between the inner edges of the squares was measured.

The femurs on both sides were exposed by means of a longitudinal incision and they were removed from the soft tissue. The femur was separated at the knee joint from shank bone. The head of the femur was enucleated from the acetabulum of the hip joint. Soft tissue was removed from the bone without disturbing the joint cartilage.

According to Martin's criteria, the greatest length of the femur was measured [1]; in other words, the rectilinear distance between the top of the head and the furthest point of the paracentral condyle (29)

\section{RESULTS}

The research points to a very close relationship between the length of a dead body and the measured, greatest length of the femur. This relationship was expressed in nine coefficients of correlation calculated for both sexes. Their value in the case of male femurs was greater. For the right- and left-side bone, the coefficient of correlation was identical and amounted to 0.923; for the average length of the bones of both sides of the body, its value was 0.925 . In the case of female femurs, the coefficients of correlation were as follows: for right femurs, 0.892; for left femurs, 0.833; for the average length of right and left bones, 0.869 . The highest coefficient of correlation (0.950) was obtained after measuring all the examined bones taken from remains of both sexes. Calculated errors in reconstruction (standard errors/standard deviations from the line of regression, $S_{a b}$ ), which affected $68 \%$ of cases, were lower with regard to the measurements taken from female bodies. All results are set out together in following tables.

Table 1 Statistical characteristics of the length of male remains $(n=71)$ and of the greatest length of femurs; equations of regression to calculate height while alive and standard deviations from the line of regression.

\begin{tabular}{cccccc}
\hline Feature & $\boldsymbol{x}^{-}$ & $\boldsymbol{s}$ & $\begin{array}{c}\boldsymbol{r}_{a b} \\
\text { (correlation factor) }\end{array}$ & Formula & $\boldsymbol{S}_{a b}$ \\
\hline $\begin{array}{c}\text { Length of the } \\
\text { individual(a) }\end{array}$ & 1748.83 & 78.44 & & & \\
$\begin{array}{c}\text { Right femur } \\
\text { (Fdx) (b) }\end{array}$ & 472.93 & 25.07 & 0.923 & $a=383.16+2.89 b$ & 30.46 \\
$\begin{array}{c}\text { Left femur } \\
\text { (Fsin)(b) }\end{array}$ & 472.73 & 25.14 & 0.923 & $a=385.37+2.88 b$ & 30.49 \\
Fdx+Fsin/2 & 472.83 & 25.03 & 0.923 & $a=375.96+2.90 b$ & 29.94 \\
\hline
\end{tabular}

$; r_{a b}$, coefficient of correlation; $S_{a b}$, reconstruction error (standard deviation from line of regression).

Table 2 Statistical characteristics of the length of female remains $(n=20)$ and of the greatest length of femurs; equations of regression to calculate height while alive and standard deviations from the line of regression

\begin{tabular}{ccccccc}
\hline Feature & $\boldsymbol{x}^{-}$ & $\boldsymbol{s}$ & $\begin{array}{c}\boldsymbol{r}_{\boldsymbol{a b}(\text { correlation }} \\
\text { factor })\end{array}$ & Formula & $\boldsymbol{S}_{\boldsymbol{a b}}$ \\
\hline $\begin{array}{c}\text { Length of } \\
\text { remains }(a)\end{array}$ & 1623.05 & 38.19 & & & & \\
$\quad \mathrm{Fdx}(b)$ & 429.92 & 12.72 & 0.892 & $a=471.25+2.68 b$ & 17.70 \\
Fsin $(b)$ & 431.68 & 13.12 & 0.833 & $a=576.93+2.42 b$ & 21.73 \\
$(\mathrm{Fdx}+\mathrm{Fsin}) / 2$ & 430.80 & 12.82 & 0.869 & $a=508.15+2.59 b$ & 19.43 \\
$(b)$ & & & & & & \\
\hline
\end{tabular}

Fdx, right femur; Fsin, left femur; $r_{a b}$, coefficient of correlation; $S_{a b}$, reconstruction error (standard deviation from line of regression).

Table 3 Statistical characteristics of the length of male and female remains $(n=91)$ and of the greatest length of femurs; equations of regression to calculate height while alive and standard deviations from the line of regression

\begin{tabular}{ccccccc}
\hline Feature & $\boldsymbol{x}^{-}$ & $\boldsymbol{s}$ & $\boldsymbol{r}_{a b(\text { correlation factor) }}$ & Formula & $\boldsymbol{S}_{a b}$ \\
\cline { 1 - 1 } & Length of & 1721.03 & 88.54 & & & \\
remains $(a)$ & & & & & \\
Fdx $(b)$ & 463.03 & 28.90 & 0.949 & $a=374.65+2.91 b$ & 28.03 \\
Fsin $(b)$ & 463.84 & 28.68 & 0.946 & $a=366.02+2.92 b$ & 28.83 \\
$(\mathrm{Fdx}+$ Fsin $) / 2$ & 463.44 & 28.73 & 0.950 & $a=364.49+2.93 b$ & 27.88 \\
$(b)$ & & & & &
\end{tabular}


Fdx, right femur; Fsin, left femur; $r_{a b}$, coefficient of correlation; $S_{a b}$, reconstruction error (standard deviation from line of regression).

\section{DISCUSSION}

The practical use of existing formulae for reconstructing height while alive from the measurement of long bones is limited. Even the studies that are recognized as the most exact -Trotter and Gleser [[12], [13]] and Fully and Pineau [[15], [16]]-as a result of their age and, in addition, as a result of their using as material ethnic groups differing from those of Poland, do not have any substantial diagnostic significance for the Polish population, and cannot be applied to that population without serious reservations. This criticism applies even more to the even older methods of Manouverier [7] and Pearson [8], which are, however, still in general use in Poland. The extension of the long bones, connected with the constant growth and destruction-which lasts until the achievement of skeletal maturity-of the simultaneously ossifying basal cartilage, is conditioned by the defined proportions of the processes that take place in them: chondroblastic, chondroclastic, and osteoblastic. These processes are subject to disturbance through the influence of a host of exogenous and endogenous factors that result in changes in length and, in consequence, in the proportions of the body. These factors are intrapopulation factors, interpopulation factors, and intergenerational factors [27]. This means that it is necessary to periodically verify the models serving to fix height while alive. It also explains the lack of a universal method that could be applied in every case of establishing the identity of unknown remains. Trotter and Gleser [13] have proved that intrapopulation changes in length affecting changes in body proportions emerge in the course of a relatively short period of time [13]. It is necessary to consider modified formulae that serve to fix height depending on racial identity or on the constitutional type of build of body [[30], [31]]. It is emphasized that when reconstructing body height while alive, the calculated height does not express actual value of that height, but rather that which the examined individual would have if he/she belonged to the population that served to establish the applied formulae. Thus the reconstructed height is, to a substantial degree, a function of the method used [30]. The data cited indicates that the reconstruction of body length from the long bones is only, seemingly, a simple task. In reality, the matter is much more complicated. In order to obtain results that are closest to height while alive, it is necessary to consider all the elements of the skeleton that determine height [[15], [20]]. In reality, this possibility only rarely occurs.

The results of the measurements taken pointed to the asymmetry of the bones of the right and left side of the body, which had been suggested by other authors [[10], [18], [30]]. The average length of left femurs was greater than that of right femurs: among women by $1.76 \mathrm{~mm}$; among men by 0.54 $\mathrm{mm}$. Such differences were, however, statistically insignificant. Telkkä also noted the greater length of left femurs; in his study, the differe nce between right and left femurs among women was closer and amounted to $1.6 \mathrm{~mm}$, while among men it had a value of $1.5 \mathrm{~mm}$ [10]. Suggestions present in earlier studies indicated that it would be reasonable to establish separate formulae for right side bones, for left side bones and for the average length of the bones on both sides.

\section{CONCLUSION}

By this research we can conclude that there is a close relationship between the individual height and the femoral length.

\section{Reference}

1. M. Orfila, Lehrbuch der gerichtlichen Medizin, Christian Ernst Kollmann, Leipzig, 1848.

2. K. Langer, Das Wachstum des menschlichen Skeletts mit Bezug auf den Riesen, Denkschr. Kaiserl. Akad. Wiss. (math.-nat. Klasse) 31 (1871) 72-76.

3. C. Toldt, Die Knochen in gerichtsärztlicher Beziehung, in: von Maschka, (o.V.), Handbuch der gerichtlichen Medizin, Laupp'sche Buchhandlung, Tübingen, 1882, p. 483.

4. P. Topinard, Eléments d'Anthropologie générale, Paris, 1885.

5. J. Beddoe, On the stature of the older races of England, as estimated from the long bones, JRAI 17 (1887/1888) 202-207.

6. F. Rollet, De la mesuration des os longs des membres, Lyon, 1888.

7. L. Manouverier, Determination de la taille d'apres les grands os des membres, Mem. Soc. d'Anth. 2e ser. 4 (1893) 347-402.

8. K. Pearson, Mathematical contributions to the theory of evolution, in: On the reconstruction of the stature of prehistoric races, Philos. Trans. R. Soc. London, 192 (1899) 169-244.

9. Breitinger, E. Zur Berechnung der K rperh he aus den langen Gliedmassenkonchen. Anth. Anzeig.1937; 14: 249

10. Telkkä, A. On the prediction of human stature from the long bones. Acta Anat. 1950; 9: 103-11

11. Dupertuis, C.W. and Hadden, J.A. On the reconstruction of stature from long bones. Ajpa. 1951; 9/1: $15-54$

12. Trotter, M. and Gleser, G.C. Estimation of stature from long bones of American whites and Negroes. Ajpa. 1952; 10/4: 463-514

13. Trotter, M. and Gleser, G.C. A re-evaluation of estimation of stature based on measurements of stature taken during life and of long bones after death. Ajpa. 1958; 16/1: 79-123

14. Lorke, D., Münzner, H., and Walter, E. Zur Rekonstruktion der Körpergröße eines Menschen aus den langen Gliedmaßenknochen. Z. Gerichtl. Med. 1953; 42: 189-202

15. Fully, G. Une nouvelle méthode de la taille. Ann. Méd. Lég. 1956; 26: 266-273

16. Fully, G. and Pineau, H. Détermination de la stature au moyen du squelette. Ann. Méd. Lég. 1960;40: 145-153

17. I.I. Nainis, Personen identifikation an proximalen Extremitätenknochen, Mintis, Wilno, 1972.

18. Hunger, H., Leopold, D., and Idnetifikation. Johann Ambrosius Barth, Leipzig; 1978

19. W.M. Krogman, M.Y. şcan, the human skeleton in forensic medicine, Charles C. Thomas, Springfield, 1986. 
20. R. Penning, Alterskorrelierte Schatzung der Körpergröße anhand der Längen der Extremitätenknochen, Habilitationsschrift LMU, München, 1990.

21. Strzałko, J. Metody rekonstrukcji wzrostu człowieka na podstawie pomiarów szkieletu. Przegl. Antropol. 1971; 37: 295-314

22. Młodziejowski, B. Zarys osteologii sądowo-lekarskiej. Akademia Spraw Wewnętrznych, Warszawa; 1988

23. Derobert, L. Medicine Legale. Flammarion Medicine Sciences, Paris; 1974

24. Oechmichen, M. and Geserick, G. Osteologische Identifikation und Altersschätzung. Schmidt-Römhild, Lübeck; 2001

25. Mueller, B. and Gerichtliche Medizin. Springer-Verlag, Berlin; 1975

26. Prokop, O. Forensische Medizin. VEB Verlag Volk u, Gesundheit, Berlin; 1966

27. Malinowski, A. and Strzałko, J. Antropologia. PWN, Warszawa; 1985

28. Godycki, M. Zarys Antropometrii. PWN, Warszawa; 1956

29. Martin, R. and Saller, K. Lehrbuch der Anthropologie. Fischer, Stuttgart; 1957
30. Gralla, G. Długość szkieletu in situ a wzrost wyliczony z kości długich. Mat. Antropol. 1964; 65: 241-267

31. Gralla, G. Rekonstrukcja wysokości ciala z kości długich. Przegl. Antropol. 1976; 42: 259-264

32. Kurth, G. Einige Probleme der Körperhöhenbestimmung aus den langen Gliedmaßenknochen.Homo. 1954; 5: 170-178

33. Mendes-Correa, A.A. Le taille des Portugais d'aprés les os longes. Anthropology. 1932; 10: 268-272

34. Snow, C.C. and Williams, J. Variation in premortem statural measurements compared to statural estimates of skeletal remains. J. Forensic Sci. 1971; 16: 455

35. Thieme, F.P. and Schull, W.J. Sex determinations from the skeleton. Hum. Biol. 1957; 29: 242-273

36. E. Springer, Arbeitsphysiologische und arbeitshygienische Forderungen an die Gestaltung der Arbeitsmittel, des Abeitsplatzes, der Arbeitsräume und der sanitären Nebenräume, Arbeitswissenschaftliche Lehrbriefe 7, Tribüne, Berlin, 1970.

37. B. Rother, Möglichkeiten und Grenzen der Körperhöhenrekonstruktion aus den Maßen langer Röhrenknochen, Inaugural. Diss., Leipzig, 1970.

38. Saller, K. Der Geschlechtsunterschied im Verhältnis Stammlänge zu Körpergröße beim Menschen.Z. Konstit.-lehre. 1931; 16: 81-92

\section{How to cite this article:}

Dharahaas (2017) ' Estimation of Individual Height in Correlation With Femur Length', International Journal of Current Advanced Research, 06(03), pp. 2890-2893.

DOI: http://dx.doi.org/10.24327/ijcar.2017.2893.0134 